\title{
Analysis of Egg Price Fluctuation and Cause
}

\author{
Wu Yuhuan ${ }^{1} \&$ Qin $\mathrm{Fu}^{1}$ \\ ${ }^{1}$ Institute of Agricultural Economics and Development, Chinese Academy of Agricultural Sciences, Beijing, \\ China
}

Correspondence: Qin Fu,Institute of Agricultural Economics and Development, Chinese Academy of Agricultural Sciences, 100081, China. Tel: 86-010-8210-9780. E-mail: qinfu@caas.cn

Received: August 3, 2018

doi:10.5539/jas.v10n11p581

Accepted: September 2, $2018 \quad$ Online Published: October 15, 2018

URL: https://doi.org/10.5539/jas.v10n11p581

\begin{abstract}
In 2017, egg price in China has experienced a lot of ups and downs, which has had a significant impact on the laying hen farmers and the enterprises and related enterprises. In the first half of 2017, egg price fell, which has dropped to a minimum of $4.02 \mathrm{yuan} / \mathrm{kg}$, while the profits of egg producers were impaired and the profit of egg processing enterprises declined. Starting in July, egg price recovered, breaking a price of $5 \mathrm{yuan} / \mathrm{kg}$. Egg price rose sharply in August, reaching an average of 8.53 yuan $/ \mathrm{kg}$. In October, egg price began to fall, with a price of 7 yuan $/ \mathrm{kg}$. In November, egg price began to rise, rising to 8 yuan $/ \mathrm{kg}$. The sudden drop of egg price greatly affects the income and culture psychology of laying hen farmers, and influences the development of the egg industry. This study is aimed at egg price and egg price fluctuations in 2017, and get two conclusions: From January to July, due to the amount of laying hens breeding, breeding cost, information technology and the government's environmental protection policy and terminal weak consumer spending, egg price fell sharply; egg price rebounded in August and December, and the highest price was in September and gradually steadied. At the same time, this paper analyzes the causes of egg price fluctuation from two aspects of supply and demand, and puts forward some suggestions on how to deal with the price fluctuations from the two aspects of enterprise and laying hen breeding farmers.
\end{abstract}

Keywords: egg price, main egg production area, price fluctuation, fluctuation cause

\section{Introduction}

There are about 3.85 billion laying hens in the world and about 1.35 billion laying hens, accounting for about $35 \%$ of the world volume of laying hens, in China. China has a large egg production and a rapid development of laying-hens breeding industry. At present, China is the world's largest producer of poultry egg, accounting for about $40 \%$ of the world's poultry egg production. Due to the large volume of laying hens, China can achieve self-sufficiency at the rate of $100 \%$. According to statistics from the National Bureau of Statistics of China, the total production of egg in China in 2015 was 29,992,200 tons. Regarding the data of FAO in 2014, China's egg production accounted for $86.19 \%$ of the total number of poultry egg. Based on this, we can know that, in 2015 , China's egg production was $25,855,500$ tons, and in 2016, China's egg production was $26,675,800$ tons.

Egg price has been running at a low level since the autumn of 2016 in China, and remain at a low level during the Spring Festival in 2017. Egg price continued to fall across the country in the first half of 2017. The low egg price not only affects the enthusiasm of laying hen breeding farmers, but also hampers the healthy development of egg processing enterprises. By analyzing the long-term and short-term fluctuations of egg price, the reasons for the fluctuations of egg price can be obtained. The short-term egg price can be predicted based on the existing data, which plays an important role in guiding farmers and related enterprises to adjust their production decision-making behaviors.

The price of eggs directly affects the balance of supply and demand in the egg market, and increasing producer price would be an effective incentive for increasing production (Afolami et al., 2003). Egg farmers are sensitive to the egg price (Afolami \& Oladimeji, 2003). So the study of egg price is of great significance to farmers. Egg price fluctuation is divided into long-term trend and short-term trend fluctuation (Maynard, 1997). Long-term trend analysis is conducive to macro control of egg prices. The short-term trend is favorable for producers to adjust their production behavior (Rezitis, 2017). Egg price is affected by a number of factors (Strong et al., 2012), 
such as seasonal factors, demand situation (Goto, 2008), Feed price (Babula \& Bessler, 2009) and so on. Egg price forecasts are good for industry (Ahmad et al., 2001; Roy, 1971; Ahmad \& Mariano, 2006).

There have been many previous studies on egg price. Based on previous studies, this paper comprehensively and carefully analyzed the fluctuations of egg price and its causes, and analyzed the abnormal egg price in 2017 and the first half of 2018, which is conducive to the formulation of policies and the development of egg industry.

\section{Materials and Methods}

\subsection{Data Source}

The data we use is download from website: http://www.caaa.cn/. The price data is monthly and the unit is yuan $/ \mathrm{kg}$. The sample interval was from January 2000 to June 2018, and the overall trend of egg prices was obtained by using monthly data of egg price.

\subsection{Methods}

We use descriptive statistics analysis to elaborate egg price fluctuation since January 2000. Descriptive statistical analysis can be more intuitive to show the long-term trend of egg price fluctuations.

We use use the method of BP to calculate the cycle time of egg price meanwhile.BP filter is a kind of general empirical analysis method for price analysis. The principle of BP analysis is to treat time series as the superposition of different harmonics and study the structural characteristics of time series in a frequency domain. The variation of time series $\mathrm{X}$ can be decomposed into the superposition of various frequency fluctuations, which is usually decomposed by linear filtering, and BP analysis is to use band pass filtering in linear filtering for analysis.

\subsection{Objectives of the Study}

1) To comprehensive analysis long-term change and short-term fluctuation of egg price.

2) To find out why egg prices went up and down2017 and the first half of 2018.

3) To suggest recommendations based on the analysis results

\section{Result}

\subsection{Descriptive Statistics Analysis of Long-Term Price Fluctuation in China's Egg Market}

In the past 17 years, the general trend of egg price in China is on the rise. From 2000 to the end of 2003, the price of eggs was relatively stable, with an average price of 5 yuan $/ \mathrm{kg}$ fluctuating. Since the end of 2003, China entered the upward trend of volatility. In February 2011, the average national egg price exceeded 10 yuan $/ \mathrm{kg}$, which doubled from June 2003. In November 2011, the price of eggs dropped from a high level. In May 2012, the national average price of eggs dropped to 8.23 yuan $/ \mathrm{kg}$, and then the price began to recover. Since 2013, egg price in China has maintained a high level. At the beginning of 2013, egg price was as high as $10.97 \mathrm{yuan} / \mathrm{kg}$, which dropped to 9.93 yuan $/ \mathrm{kg}$ by the end of 2013. In 2014, egg price was rising all the way. In September, egg price has risen to 12.2 yuan $/ \mathrm{kg}$. The average egg price remained at 10 yuan $/ \mathrm{kg}$ in 2015. In 2016, egg price began to drop. As can be seen from the trend chart of egg price from 2013 to 2017, from January in 2013 to October in 2014, egg price was on the rise, with the highest price being 12.2 yuan $/ \mathrm{kg}$, the lowest price being 9.1 yuan $/ \mathrm{kg}$, and the price difference being $3.1 \mathrm{yuan} / \mathrm{kg}$. From 2014 to June in 2017, egg price showed a downward trend (as shown in Figure 1).

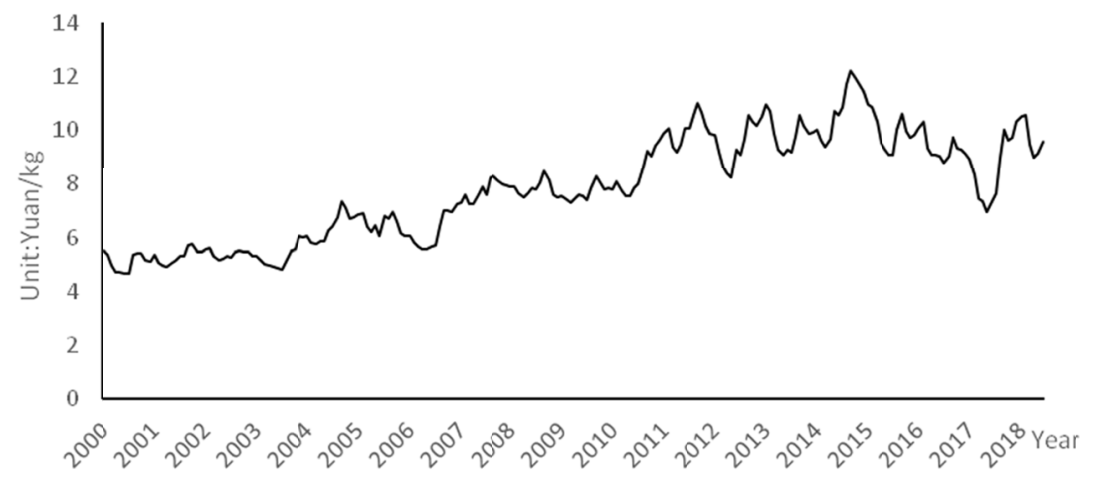

Figure 1. Egg price trend chart from January 2000 to June 2018 


\subsection{Analysis on the Short-Term Price Fluctuation in China's Egg Market}

We used BP analysis to study the short-term price fluctuation from 2000. In Figure 2, the horizontal axis represents Year. The vertical axis represents the difference in actual egg prices after the time trend has been removed, and we can see that the annual cycle of egg price in China is 3 years. Breeding domestic laying hens last about 500 days from chicken seedlings to the end of egg production. Therefore, it takes about 3 years $(500 \times$ $2=1000$ days $=3$ years) for egg price from rising to falling.

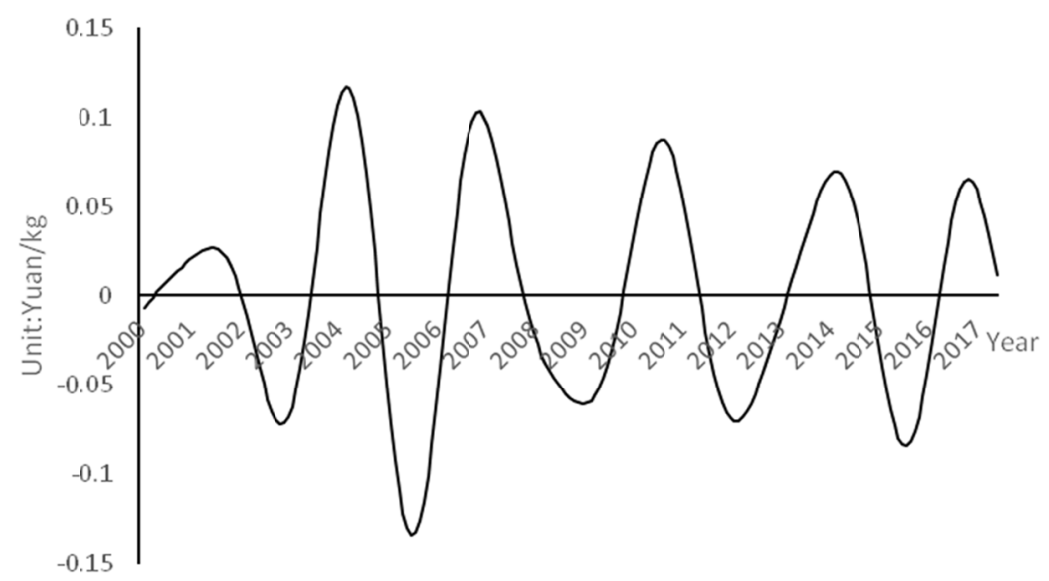

Figure 2. Egg price characteristics during the year

From the perspective of the characteristics of egg price in one year, egg price presents the characteristics of low in spring and high in autumn (see Figure 3), which is mainly influenced by seasonal effects of production and epidemics. The temperature is suitable in spring, and egg-laying season begins.The egg market was well supplied and the price of eggs dropped. The summer temperature is higher and the laying rate of laying hens decreases.As egg production and market volume decrease, then the egg market was in short supply and the price of eggs rose. In autumn and winter, as a result of temperature drop, coupled with the impact of the Mid-Autumn festival, Spring Festival, egg prices rise. So egg price presents the characteristic of "spring low autumn high".

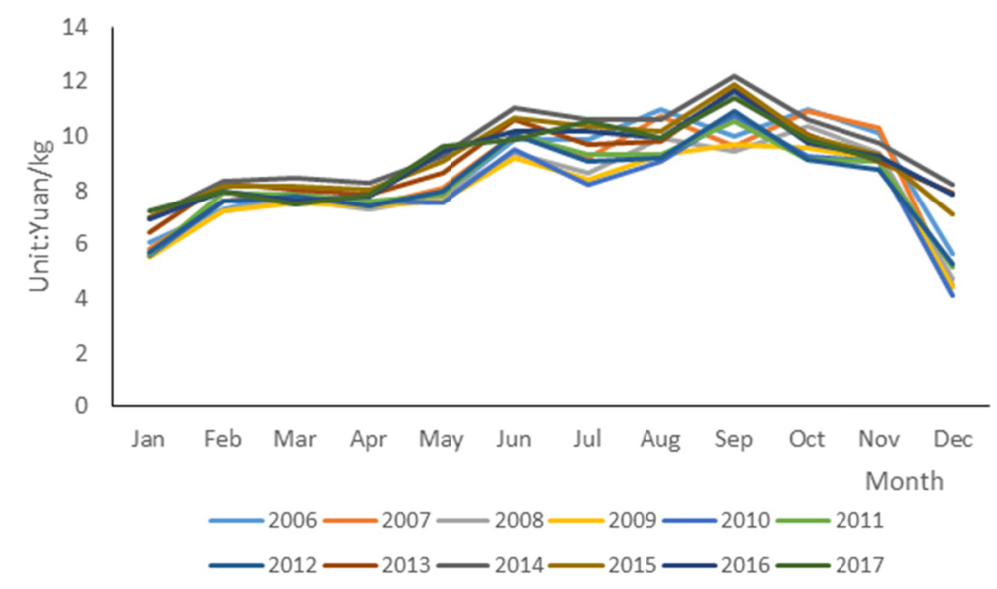

Figure 3. Annual cycle of egg price

Source: Egg Industry Network.

\subsection{Analysis of Egg Price in 2017 and the First Half of 2018}

Egg price dropped to lowest level in nearly a decade in the first half of 2017. The egg market has been greatly affected. In the second half of 2017, egg prices started to pick up. And the egg price rebound trend continues into 
the first half of 2018. The egg price analysis in the first half of 2017-2018 is representative, which is conducive to the following egg price warning and egg market monitoring. As can be seen from Table 1, egg price of China in 2017 can be divided into 3 stages based on the price. In the first stage, the egg price is higher than 5 yuan $/ \mathrm{kg}$. In the second stage, the price of eggs is less than 5 yuan $/ \mathrm{kg}$. In the second stage, the price of eggs rebounded to over 5 yuan $/ \mathrm{kg}$.

Table 1. Egg price from October 2016 to June 2018 (Unit: yuan/kg)

\begin{tabular}{lll}
\hline Year & Month & Egg Price \\
\hline 2016 & October & 9.34 \\
& November & 9.27 \\
& December & 9.13 \\
\hline 2017 & January & 5.66 \\
& February & 4.45 \\
& March & 4.72 \\
& April & 4.43 \\
& May & 4.14 \\
& June & 5.14 \\
& July & 5.24 \\
& August & 7.92 \\
& September & 8.21 \\
& October & 7.11 \\
& November & 7.83 \\
& December & 8.65 \\
\hline 2018 & January & 10.55 \\
& February & 10.59 \\
& March & 9.49 \\
& April & 9.01 \\
& May & 9.12 \\
& June & 9.58 \\
\hline
\end{tabular}

\subsubsection{Stage 1: January}

From egg price in previous New Year's day, the national egg price showed a downward trend. During the New Year's day, egg stocks are high in various places, the arrival of goods in the sales area increased, egg price stabilized.The end of 2016 is the end of a 3-year cycle of egg price. Therefore, based on the 3-year cycle calculation, egg price will show a downward trend in 2017. But factors such as laying hens, disease and consumer psychology also influence egg price. In recent years, social capital has been continuously involved in the laying hens industry, meanwhile the promulgation of the national breeding environmental protection policy, the impact of bird flu epidemic and the price change of corn soya meal have been influencing the development of the laying hens industry.

\subsubsection{Stage 2: February to July}

From February to July in 2017, egg price was at a low level. From February to May, egg price was below 5 yuan $/ \mathrm{kg}$, with the lowest average price reaching 4.1 yuan $/ \mathrm{kg}$. From May to July, egg price rose slightly, and was higher than 5 yuan $/ \mathrm{kg}$. Egg price kept falling. The cause of the decline in egg price is the oversupply. The increasing number of laying hens directly leads to the increase in the supply of egg market. However, due to the influence of bird flu, the consumption of egg declines, resulting in the oversupply of egg in the market and the decline in egg price. The specific reasons are as follows:

On the supply side:

(1) The number of laying hens increased. Due to the impact of the bird flu epidemic in 2013, the stock of laying hens decreased. Thus the farmers of laying hens were cautious in making up the stocks, and the stock of laying hens decreased.So the supply of egg was less than the demand, thus egg price kept rising. The rising egg price has stimulated the enthusiasm of farmers. In the early stage, the newly added mendicant laying hens was on 
produce gradually, and the supply of egg keeps increasing, while the consumption remains the same. The oversupply of egg is difficult to change in the short term, and egg price keeps declining.

(2) The cost of breeding laying hens decreased.Feed cost is the main production cost in breeding laying hens, and the feed of laying hens is corn and soybean meal. Corn accounts for over $40 \%$ of feed cost (42-46\%), soybean meal accounts for $14-17.5 \%$ of feed cost, and feed cost accounts for about $60-70 \%$ of laying hens breeding cost. So, corn and soybean meal price changes directly affect egg price. Under the comprehensive influence of the national policy adjustment and various aspects, the national corn price continues to operate at a low level, which is good for laying hens breeding farmers and reduces the pressure on feedstuff of farmers. As a result, the psychological expectation of the practitioners of profits is increased. The cost of breeding is directly related to egg price. Since the autumn of 2014, the price of corn and soybean meal has gradually decreased, which directly leads to the reduction of the cost of laying hens. The supply of egg continued to overshoot and egg price fell further.

(3) Development of information technology. The continuous progress of information technology has provided convenient conditions for laying hens breeding farmers. On the one hand, the management efficiency of laying hens was improved; on the other hand, the diagnosis and prevention of chicken diseases were realized conveniently and quickly. It has boosted the overall capacity of farmers and increased the supply of egg.

(4) Capital intervention. In the past two years, the development of animal husbandry has been in a good state, and external investors have been continuously entering the laying-hens industry. In 2016, a large amount of external capital has been flowing into the laying-hens industry, and the competition in the egg market will be even more fierce in 2017. At the same time, financial leasing and egg-laying insurance provide strong support for the expansion of laying-hens, increase the supply of egg market, and aggravate the situation that egg supply exceeds demand.

(5) The impact of the government's environmental policy. Due to the implementation of a series of environmental protection policies, the elimination of chickens cannot be eliminated until the end of time. Egg production continues.

From the demand side:

(1) The impact of avian influenza epidemic. In 2016, the occurrence of bird flu epidemic events, bird flu outbreak in Europe, Asia and other places. Consumers are cutting back on egg because of the disease. At the same time, in order to cope with the avian influenza epidemic, the government has adopted live poultry control measures, and the elimination of chickens has been hindered, and the stock of laying chickens remains high.

(2) The development of e-commerce platform. The development of e-commerce has promoted the online fresh food trade, the online and offline tearing price wars, and egg price lacks stability.

(3) The current domestic housing price is high, and the overall economic environment is not optimistic. The downward pressure on the economy has a lagging effect on consumption through employment and income channels. The pressure on citizens' living increases, and the consumption power is slightly affected.

\subsubsection{Stage 3: August and December}

From August to December, egg price began to rise sharply, and then in early August and September, when food companies were preparing for the Mid-Autumn festival National Day, egg price continued to surge. The market for egg has generally strengthened since August. Recently, there has been greater growth. Farmers are full of confidence, strong intention to fill the fence.

The specific reasons are as follows:

(1) From the perspective of supply, in the first half of the year, laying hens breeding farmers suffered a large loss, and the stock of existing laying hens decreased significantly. According to Zhihua data, by May, the number of laying hens in China was 1.068 billion, down $5.9 \%$ from the previous month, down $14.49 \%$ from the previous year, reached the lowest level since 2010. After June, after a wave of rising prics, as well as the expected increase in egg price in the later period, the amount of chicken panning slowed down and the number of additional columns increased slightly.

(2) In terms of demand, egg consumption remained sluggish in the first half of the year due to the impact of avian influenza. In the second half of the year, judging from seasonal fluctuations in egg price, August and September are the most likely to rise, and the second half of the year is expected to turn a profit. Schools will open in August and September, as well as the need to stock up for double holidays, which boost egg price. 
As the public and relevant national organizations pay attention to food safety issues, the quality and safety of egg will inevitably come into the attention of the public. Also, the weather turns cold and the laying hens enter a period of frequent influenza.

Egg price showed a slight upward trend in the first half of 2018, followed by a drop. After experiencing the price downturn, egg price exceed 10 yuan $/ \mathrm{kg}$ from the beginning of 2018, and slightly drop to 9 yuan $/ \mathrm{kg}$ from March.

\section{Conclusions}

(1) In 2017, egg price in China experienced great ups and downs, which had a great impact on farmers and related enterprises. In January-July period, egg dropped sharply, to the lowest point, and the farmers and enterprises of laying hens bear loss. On the one hand, due to the influence of the breeding quantity of laying hens, the raising cost of laying hens, the information technology and the government's environmental protection policy, the egg production is large. On the other hand, egg terminal consumption is weak, which is hard to change in the short term, so egg price in the first half of the year is falling.

(2) From August to December, egg price rose, which was the highest in September, and then gradually stabilized. In the first half of 2018, egg price is expected to run smoothly at a high level. Due to the reduction in the stock of laying hens, as well as the weakening of the impact of bird flu, egg price gradually recovered, coupled with the double knot effect, and egg price reached up to 10 yuan $/ \mathrm{kg}$.

\section{Recommendations}

Egg price is an important factor affecting the laying hens breeding farmers. As can be seen from the huge fluctuation of egg price in 2017, China's laying hens breeding farmers and enterprises are still weak in responding to egg market price. The following Suggestions are proposed:

For egg-laying chicken breeding and egg processing enterprises:

\section{(1) Egg branding operation}

Sticking to the road of branding and improving consumer loyalty is a good way to stabilize consumer demand. A brand maintains a special relationship between the customer and the product and conveys the quality and value of the product. In egg market, consumers are more likely to buy trustworthy products. Therefore, when egg price is low, the brand effect of egg is more prominent. Taking the road of branding operation, we can reduce the price fluctuation of egg market and improve the enterprise's ability to resist risks. Make the brand big and get the pricing power.

\section{(2) Pay attention to egg safety}

Keep the laying hens well to protect against risk. In the case of market downturn, more attention must be paid to bio-safety and food safety. Food quality safety is a magic weapon for enterprises to make profits under the condition of low price.

\section{(3) Grasp the market situation}

Establish information-based breeding, timely access to egg market price data. We will establish and improve the egg trading market, and realize the professionalization, standardization, industrialization and informatization of egg management. Improve Tracking and forecasting ability of the market situation, according to the market situation of prospective judgment to make proposals for agricultural production and breeding, and guide farmers to arrange related production and breeding plan in advance, avoid unnecessary losses.

Farmers of laying hens:

(1) Actively follow market trends and make reasonable decisions. Due to the particularity of agricultural production, the production decision of farmers has a certain lag. In order to make a reasonable decision, we must make full use of the existing market information and accurately predict the domestic and international future market trends. This requires farmers to keep their information sharp and keep an eye on the market trend of egg price through newspapers, media, television and the Internet.

(2) Make full use of future market instruments to reduce the loss of spot price volatility. Futures markets have two main functions: price discovery and hedging. In the future, egg price can be reflected by the egg futures market. All buyers and sellers can quote through the futures market. In the futures market, even if egg price fluctuates sharply, buyers and sellers can lock in the cost price and avoid property losses.

At present, there are futures products for agricultural products such as egg in the domestic futures market. Large breeding enterprises and farmers can use relevant futures products to hedge their spot and lock in relevant 
breeding costs and profits in advance, so as to reduce the loss caused by possible price fluctuations in the breeding process.

(3) Make full use of modern science and technology. New technologies such as Internet e-commerce are used to reduce the information asymmetry between supply and demand in market. The new technologies and platforms of the Internet are utilized to directly connect the production and demand of agricultural products by developing order agriculture online. To reduce the information asymmetry between the supply and demand of agricultural products stabilize the price of agricultural products.

\section{Reference}

Afolami, C. A., \& Oladimeji, O. (2003). Producer response to retail egg price in Ogun state Nigeria: Implications for increased egg production. Nigerian Journal of Animal Production, 30(1). https://doi.org/10.4314/ njap.v30i1.3317

Ahmad, H. A., \& Mariano, M. (2006). Comparison of forecasting methodologies using egg price as a test case. Poultry Science, 85(4), 798-807. https://doi.org/10.1093/ps/85.4.789

Ahmad, H. A., Dozier, G. V., \& Roland, D. A. (2001). Egg Price Forecasting Using Neural Networks. Journal of Applied Poultry Research, 10(2), 162-171. https://doi.org/10.1093/japr/10.2.162

Babula, R. A., \& Bessler, D. A. (2009). The corn-egg price transmission mechanism. Journal of Agricultural \& Applied Economics, 22(2), 79-86. https://doi.org/10.1017/s1074070800001838

Goto, N. (2008). Egg price prediction model for the Japanese egg industry. Jap Poult Sci. https://doi.org/10.2141/jpsa.11.10

Maynard, L. J. (1997). Price discovery in the egg industry. Agricultural \& Resource Economics Review, 26(1), 23-30. https://doi.org/10.1017/s1068280500000800

Rezitis, A. N. (2017). Empirical analysis of price relations along the Finnish supply chain of selected meat, dairy, and egg products: A dynamic panel data approach. Agribusiness, 4. https://doi.org/10.1002/agr.21536

Roy, S. K. (1971). Prediction of Shell Egg Price-A Shortrun Model. Southern Journal of Agricultural Economics, 3(1), 175-179. https://doi.org/10.1017/s008130520001030x

Strong, S. M., \& Wolanowski, A. M. (2012). A queueing model for egg price determination. Australian Journal of Agricultural \& Resource Economics, 25(2), 170-175. https://doi.org/10.1111/j.1467-8489.1981.tb00394.x

\section{Copyrights}

Copyright for this article is retained by the author(s), with first publication rights granted to the journal.

This is an open-access article distributed under the terms and conditions of the Creative Commons Attribution license (http://creativecommons.org/licenses/by/4.0/). 